\title{
Author response: The relationship between mean platelet volume and inflammation in varicocele pathophysiology
}

\section{Coban Soner, $M D ;{ }^{*}$ Keles Ibrahim, $M D ;{ }^{*}$ Biyik Ismail, MD; Guzelsoy Muhammet, MD;* Turkoglu Ali Rıza, MD;* Ocak Nihal, $M D^{\S}$}

*Department of Urology, Sevket YImaz Training and Research Hospital, Bursa, Turkey; ${ }^{*}$ Department of Urology, School of Medicine, AfyonKocatepe University, Afyonkarahisar, Turkey; „Department of Obstetrics and Gynecology, Karacabey State Hospital, Bursa, Turkey; §Department of Biochemistry, Şevket Ylmaz Training and Research Hospital, Bursa, Turkey.

Cite as: Can Urol Assoc J 2015;9(9-10):E640. http://dx.doi.org/10.5489/cuai.3253 Published online September 9, 2015.

W e have read the Letter to the Editor by Demirer and colleagues with great interest. ${ }^{1}$ We would first like to thank the authors for their interest in and contribution to our work.

Interleukin (IL)-1, IL6, IL-8 and TNF- $\alpha$, all cytokines that are active in infection and inflammation, are reported to possibly play a role in the etiology of male infertility and with potential diagnostic use in such pathologies..$^{2-6}$ However, we did not come across any study reporting a role in varicocele pathophysiology. MPV values have been reported to be high during the active period of inflammatory condi- tions (ankylosing spondylitis, rheumatoid arthritis), decreasing to normal after treatment. ${ }^{7}$ This supports a relationship between MPV and inflammation. However, varicocele is mainly a vascular pathology with endothelial dysfunction as the main pathogenetic factor. ${ }^{8}$ We believe any relationship can be better demonstrated in a study evaluating inflammation markers (IL-1, IL-6, IL-8 and TNF- $\alpha$ ) together with MPV.

Our study is significant as it is the first in the literature on this subject and we believe studies on larger series are required as stated in our conclusions.

Competing interests: The authors all declare no competing financial or personal interests.

\section{References}

1. Demirer Z, Uslu AU. More work needed in examinging the relationship between mean platelet volume and inflammation in varicocele pathophysiology. Can Urol Assoc J 2015;9:E639. http://dx.doi. org/10.5489/cuaj.3114

2. Huleihel $M$, Lunenfeld $E$, Horowitz $S$, et al. Expression of IL-12, IL-10, sll-2R and sll-6R in seminal plasma of fertile and infertile men. Andrologia 1999;31:283-8. http://dx.doi.org/10.1046/i.1439$0272.1999 .00289 x$

3. Matalliotakis I, Kiriakou D, Fragouli I, et al. Interleukin-6 in seminal plasma of fertile and infertile men. Arch Androl 1998;41:43-50. http://dx.doi.org/10.3109/01485019808988545

4. Gruschwitz MS, Brezinschek R, Brezinschek HP. Cytokine levels in the seminal plasma of infertile males. J Androl 1996; 17:158-163.

5. Koumantakis E, Matalliotakis I, Kyriakou D, et al. Increased levels of interleukin-8 in human seminal plasma. Andrologia 1998;30:339-343. hitp://dx.doi.org/10.1111/j.1439-0272.1998.tb01180.x

6. Paradisi $R$, Mancini $R$, Bellavia $E$, et al. T-helper 2 type cytokine and soluble interleukin-2 receptor levels in seminal plasma of infertile men. Am J Reprod Immunol 1997;38:94-9. http://dx.doi. org/10.1111/i.1600-0897.1997.tb00282.x

7. Yazici S, Yazici M, Erer B, et al. The platelet indices in patients with rheumatoid arthritis: Mean platelet volume reflects disease activity. Platelets 2010;21:122-5. http://dx.doi.org/10.3109/09537100903474373

8. Tek $\mathrm{M}$, Cayan $\mathrm{S}$, Yilmaz $\mathrm{N}$, et al. The effect of vascular endothelial growth factor on spermatogenesis and apoptosis in experimentally varicocele-induced adolescent rats. Fertil Steril 2009;9:2247-52. http:// dx.doi.org/10.1016/i.fertnstert.2008.06.008

Correspondence: Soner Coban, Department of Urology, Sevket Yilmaz Training and Research Hospital, 16260, Yildirim/Bursa, Turkey; sonercoban75@mynet.com 